\title{
$\mathrm{PC}$ MIDI와 USB Interface를 이용한 전자건반악기 개발
}

\author{
임 기 정*, 이 정 철*

\section{An Electronic Keyboard Instrument Using PC MIDI and USB Interface}

\author{
Gi-Jeong Lim*, Jung-Chul Lee*
}

\section{요 약}

음악교육은 창의력, 사회성, 학업 성취도를 향상시킨다. 음악교육에 있어서 학습자들이 수동적으로 지식을 전달 받기보다는 자기 수준에 맞는 내용을 선택하여 자신의 학습속도에 맞춰 스스로 학습할 수 있는 학습자 중심의 교육 이 강조되고 있다. 이에 따라 자신의 학습 수준, 속도에 맞게 학습할 수 있는 학습도구의 개발이 요구되고 있고, 특 히 자율학습이 가능한 전자 악기 $\mathrm{HW}, \mathrm{SW}$ 에 대한 요구가 높아지고 있다. 그러나 기존의 전자악기와 $\mathrm{PC} \mathrm{MIDI}$ 를 이용한 software들은 초등학교 저학년 학생들이 악기연주 자율학습에 활용하는데 어려움이 있다. 본 논문에서는 이들 문제점들을 해결하기 위해 $\mathrm{PC}$ 환경에서 $\mathrm{PC}$ 와 USB Interface로 통신 가능한 외장 전자 건반악기와 $\mathrm{PC}$ 기 반 software로 구성되는 악기연주 자율학습 지원도구 구현방법을 제안한다. 외장 전자건반모듈은 USB를 지원하

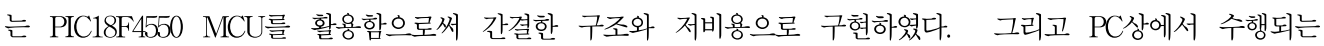
software는 악보편집, $\mathrm{MIDI}$ 정보 처리, 외장 전자건반모듈과의 상호연동을 통하여 건반악기와 유사한 환경을 지원 함으로써 향후 자율학습용 컨텐츠가 추가될 경우 전자건반악기 연주 자율학습에 활용이 가능하다고 판단된다.

- Keyword : 전자건반악기, 자율학습 프로그램, MIDI

\section{Abstract}

The music education improves the creative talent, social skills and academic achievement of the students. For the efficient music education, the learner centered study is highly recommended rather than the passive education, which supports self-control in selecting teaching materials,

- 제1저자 : 임기정 • 교신저자 : 이정철

- 투고일 : 2011. 10. 05, 심사일 : 2011. 10. 24, 게재확정일 : 2011.11. 14.

* 울산대학교 컴퓨터정보통신공학부(School of Computer Engineering \& Information Technology, University of Ulsan) 
learning patterns and speed. For the successful self learning, it is requested to develop the collaborative educational learning tools, especially electronic collaborators such as $\mathrm{H} / \mathrm{W}$ and $\mathrm{S} / \mathrm{W}$. Though there exist many commercialized electronic instruments and the PC MIDI based softwares, these tools have some limits and problems for the primary student to learn playing the musical instrument by himself. In this paper, we propose a supporting tool implementation method using an electronic keyboard instrument with USB Interface and PC-based software to help the primary student to learn playing the musical instrument. We implemented an electronic keyboard instrument module compactly and at low cost using a PIC18F4550 MCU. PC based software was developed to edit musical score, process the MIDI information, and interact with the electronic keyboard instrument module. This tool can offer a similar keyboard instrument environment and can be incorporated with self learning contents.

- Keyword : Electronic Keyboard Instrument, Self-study program, MIDI

\section{I. 서 론}

최근 연구에 따르면 음악 교육을 받은 학생의 수학, 읽기, 과학, 사회 등의 교과목 성취도가 훨씬 높고, 사회/경제적 지 위 또한 학업 성취와 상관도가 크다는 연구 결과가 있다[1]. 이처럼 음악학습은 학생들의 학업 성취도를 높일 뿐만 아니 라, 학생들의 창의성과 사회성을 향상시키는데 중요한 역할을 하고 있다. 이러한 음악학습의 중요성과 더불어 음악교육에서 도 다양한 교육 개혁이 일어나고 있으며 그 중에서도 학습자 중심의 교육이 강조되고 있다[2]. 학습자 중심의 교육을 위 해서는 학습자들이 능동적으로 자기 수준에 맞는 학습 내용을 선택하여 자신의 학습 방식과 속도, 수준에 맞게 학습할 수 있는 장치의 개발이 요구되는데, 이러한 요구에 의해 음악교 육 분야에서는 전자악기에 대한 필요성이 높아지고 있다.

전자악기와 관련된 연구로는 디지털 악기 모델링에 관련된 연구들이 활발히 진행되고 있다[3-6]. 전자악기와 관련된 Interface의 경우 줄 없는 기타, $\mathrm{MIDI}$ 를 활용한 전자 음악 장갑, 뮤직XML을 이용한 응용프로그램 등이 연구되었고 $\mathrm{MIDI}$ 를 게임효과에 사용하여 현실감을 구체적으로 표현하고 자 하는 게임이벤트 처리 관련 연구도 진행되고 있다[7-9]. 그리고 상업화된 전자악기로는 미국의 ICON digital, 일본 의 Roland, 야마하, KORG사의 마스터 키보드들을 비롯하 여 Wind 미디 컨트롤러인 AKAI professional사의 Akai EWI4000S, 야마하사의 WX5 YAMAHA Midi Controller 등이 있으며, 전자악기 관련 산업도 지속적으로 발전하고 있 다[10-11]. 이러한 외부 미디모듈을 이용한 제품 뿐만 아니 라 $\mathrm{PC} \mathrm{MIDI}$ 를 이용한 상용화된 software들로는 Finale, Sibelius, Encore, Sonar, Cubase 등 이 출시되어 사용되

\section{고 있다[12].}

앞서 살펴본 바와 같이 전자악기와 관련된 다양한 연구들 과 다양한 상용제품들이 사용되고 있으나 초보자 특히 초등학 교 저학년 학생들이 건반악기 연주를 배우는데 있어 학습자 중심의 교육에 중점을 둔 소프트웨어나 하드웨어와 관련된 연 구 및 제품은 미흡한 실정이다. 상용화된 전자악기와 소프트 웨어들은 상호 독립적이기 때문에 서로 연동이 되지 않을 뿐 만 아니라 각각의 가격이 비싸고 해당 제품을 사용함에 있어 전문성이 요구되어 초등학교 저학년 학생들이 악기 연주 및 학습에 어려움이 있다.

따라서 악기연주 학습자들이 악기를 접함에 있어서 고가 악기로 인한 경제적 부담감과 악기연주 실습과정에서 발생되 는 소음 문제를 해결하고, 초등학교 저학년 학생들이 쉽게 자 기주도적으로 음악학습을 할 수 있는 외장전자악기와 소프트 웨어의 통합 system이 필요하다.

본 논문에서는 일반화된 $\mathrm{PC}$ 환경에서 사용되는 전자건반 악기를 제안한다. 전자건반악기는 $\mathrm{PC}$ 와 USB Interface로 통신 가능한 외장 전자 건반모듈과 $\mathrm{PC} \mathrm{MIDI를} \mathrm{이용하는}$ software로 구성된다. 본 논문이 제안하는 외장 전자건반모 듈은 USB를 지원하는 Microchip Technology Inc.의 $\mathrm{PIC18F} 4550 \mathrm{MCU}$ 와 Firmware를 활용함으로써 간결한 구조와 저비용으로 구현이 가능하였다. 그리고 외장 전자 건 반 모듈과 연동하여 $\mathrm{PC}$ 상에서 수행되는 $\mathrm{MIDI}$ 정보 처리, 악 보구성 및 편집기능 수행이 가능하면서도 악기 초보자가 사용 하기 편리하게 구현하였다.

본 논문의 구성은 다음과 같다. $\mathrm{II}$ 장에서는 $\mathrm{PC} \mathrm{MIDI}$ 와 USB 인터페이스를 이용한 전자건반악기 기본 시스템의 구성 과 외장 전자건반모듈 설계 방법, 전자건반악기 연주를 담당 하는 소프트웨어의 설계 방법을 설명하였다. III장에서는 실 
험결과를 IV장에서는 결론을 기술하였다.

\section{PC MIDI와 USB 인터페이스를 이용한 전자건반악기 시스템의 구성}

본 논문에서 제안하는 전자건반악기는 그림 1 과 같이 $\mathrm{PC}$ 와 USB Interface를 통해 연결되어 $\mathrm{MIDI}$ 를 통해 출력장치 를 통한 출력이 이루어지도록 구성된다. 외장 건반모듈은 사 용자의 건반입력 정보를 USB통신으로 $\mathrm{PC}$ 에 전달하며, 동시 에 $\mathrm{PC}$ 로부터 건반악기연주 학습에 필요한 도움정보를 전달받 아 출력하는 기능을 담당한다. $\mathrm{PC}$ 프로그램은 외장 건반모듈 에서 입력된 음표정보로부터 음높이, 눌러진 세기 정보, 채널 정보, 음표연주 Event에 대한 정보를 분석하여 $\mathrm{MIDI}$ Message를 생성하여 PC MIDI 모듈로 전달한다. 그리고 악 보 프로그램을 통해 자신이 연주한 내용을 들어보고 편곡하고 저장하고 저장된 내용을 불러들여 예전에 작성한 연주내용을 다시 들어볼 수 있는 기능들이 포함되도록 설계 및 구현 하였다.

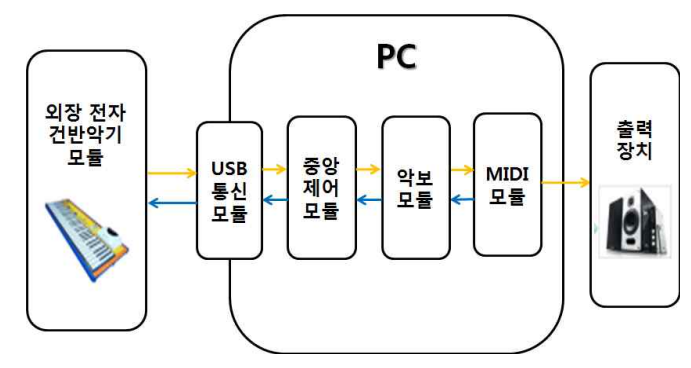

그림 1. PC MIDI와 USB interface 전자건반악기 구성도 Fig. 1. The structure of an electronic keyboard instrument using PC MIDI and USB interface

\section{1. 외장 전자건반모듈 하드웨어 설계}

외장 전자건반모듈의 구성은 그림 2와 같이 크게 $\mathrm{MCU}$ 모 듈, 건반 모듈 그리고 USB 통신 모듈로 나눌 수 있다. 건반 모듈은 건반, 누름감지 센서, 학습에 필요한 도움정보 출력장 치로 구성된다. $\mathrm{MCU}$ 모듈은 polling 방식으로 건반모듈의 상태정보를 읽어 저장한다. USB 통신 모듈은 $\mathrm{PC}$ 로부터 상 태정보에 대한 요구가 발생하면 저장된 상태정보를 USB 통 신모듈을 통해

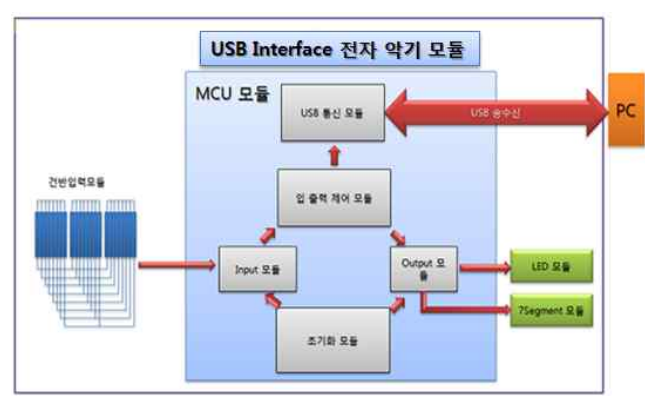

그림 2. 전자건반악기 모듈 Block Diagram Fig. 2. Block diagram for electronic keyboard instrument module

구성된 USB Interface를 통해 정보를 전달하고 동시에 $\mathrm{PC}$ 로부터 건반악기연주 학습에 필요한 도움정보를 전달받아 출력하는 기능을 담당한다.

\subsection{MCU 모듈}

전원이 공급되면 $\mathrm{MCU}$ 모듈은 Firmware를 통해 초기화 를 수행한다. 초기화 과정에서는 USB 통신의 전송속도, 전 송모드지정, EndPoint지정, EndPoint in-transaction 및 out- transaction 설정, EndPoint Size설정, Buffer Memory공간 설정(internal transceiver mode 설정), $\mathrm{PIN}$ 초기화(I/O Port의 용도 지정), USB 통신 설정 초기화 (TCON값 지정, Vendor $\mathrm{ID}$ 지정, Product $\mathrm{ID}$ 지정)를 수 행한다.

전송 속도는 충분한 polling 간격을 구현하기 위해 Full $\operatorname{Speed}(12 \mathrm{Mbps})$ 로 지정하였다. $\mathrm{PIC18F} 4550$ 은 최대 16 개 의 양방향 EndPoint를 지원한다. 1 옥타브는 흰 건반 8개, 검은 건반 5 개로 구성되며, 건반 당 1 비트로 $\mathrm{ON} / \mathrm{OFF}$ 정보 를 표시하면 모두 13 비트가 필요하므로 2 바이트를 사용한 다. 전체 4 옥타브의 건반누름 정보를 송수신하기 때문에 하 나의 EndPoint를 사용하고 buffer descriptor에 BufferSize를 64 바이트로 지정(최대 1,016 바이트)하는 것으로 충분하다. 따라서 하나의 EndPoint만 지정하였다. 이 경우 64 바이트 데이터를 주고받는다고 할 때 초당 최대 23,437회 즉 42.6us 간격(12Mbps)까지 polling 주기로 선택할 수 있다. 본 논문이 제안하는 시스템의 polling 주기 는 인지 실험을 통해 $20 \mathrm{~ms}$ 즉 초당 50 회 송수신되도록 정하 였다.

\section{2 건반 모듈}

전자건반악기를 구현함에 있어 고려해야할 문제는 많은 수 의 건반, 입력 버튼에 있다. 이는 $\mathrm{MCU}$ 의 $\mathrm{I} / \mathrm{O}$ port 수가 제 
한적이기 때문이다. 이 문제를 해결하기 위해 $\mathrm{MCU}$ 의 input port와 건반의 연결방식을 direct mapping 및 $\mathrm{AND}$ 게이트를 이용한 스캐닝 방식을 적용하였다. 흰 건반에 대한 입력처리는 그 효율성을 높이기 위해 $\mathrm{MCU}$ 와 direct mapping을 하였다. 그리고 그림 3 과 같이 사용 횟수가 상대 적으로 적은 검은 건반의 경우 octave 별로 $\mathrm{AND}$ 게이트에 묶어 스캐닝하는 방식으로 $\mathrm{MCU}$ input port와 연결 되도록 하였다.

\subsection{USB Interface 구현}

$\mathrm{PICl} 8 \mathrm{~F} 4550$ 칩 내부에 구현된 USB 인터페이스를 사용 하여 전자건반악기가 $\mathrm{PC}$ 와 손쉽게 접속 가능하도록 구성하였다.

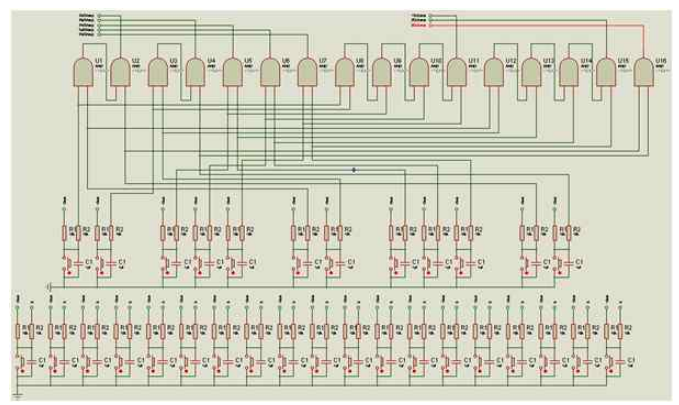

그림 3. 건반모듈 회로도

Fig. 3. Circuit of Keyboard Module

표 1. PIC18F4550의 USB통신 특성

Table 1. PIC18F4550 character for USB communication

\begin{tabular}{|c|c|c|}
\hline \multicolumn{3}{|c|}{ USB 2.0 호환가능 } \\
\hline \multirow{2}{*}{ 전송속도 } & Low Speed & $1.5 \mathrm{Mbps}$ \\
\hline & Full Speed & $12 \mathrm{Mbps}$ \\
\hline \multicolumn{3}{|c|}{ USB RAM } \\
\hline \multicolumn{3}{|c|}{ D+, D- 데이터 라인에 풀업저항 } \\
\hline \multicolumn{3}{|c|}{ On-Chip 전압 레귤레이터 } \\
\hline \multicolumn{3}{|c|}{ Data Transceiver 내장 } \\
\hline
\end{tabular}

전자건반악기에 사용되는 $\mathrm{PIC18F} 4550$ 은 표 1.과 같은 특성을 가진다. $\mathrm{PIC18F} 4550$ 은 최대 16 개의 양방향 Endpoint를 USB Status Register의 ENDP3 ENDP0 bit를 통해 설정할 수 있고 각 Endpoint마다 버퍼 크기를 지 정할 수 있다. 또 USB RAM의 Bank47을 이용하면, 각 buffer descriptor를 포함하여 $1 \mathrm{Kbyte}$ 의 공간을 활용할 수 있다. 본 논문이 제안하는 buffer descriptor 지정을 위한 최대공간인 Bank4를 제외한 나머지 Bank5 Bank7을 16 등분한 64Byte를 지정하였다. 또한 $\mathrm{PIC18F} 4550$ 의 특성 을 이용함으로써 칩 외부에 별도의 추가 회로 없이 바로 USB
통신을 구현할 수 있게 되어, 주변회로가 간단해지며 회로구 성 공간상의 이점을 추가적으로 얻게 되었다.

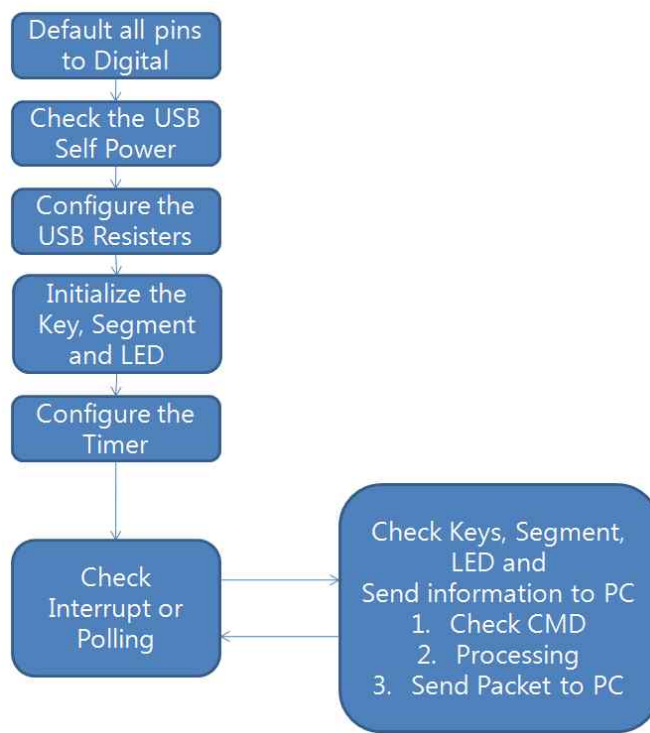

그림 4. MCU관련 Firmware 구동 흐름도 Fig. 4. Firmware flow chart for MCU

표 2. Octave 정보의 bit 구조

Table 2. Bit structure of octave information

\begin{tabular}{l|r|r|r|r|r|r|r|r|}
\cline { 2 - 7 } \multicolumn{1}{l|}{} & $0 \times 8$ & $0 \times 4$ & $0 \times 2$ & $0 \times 1$ & $0 \times 0$ & $0 \times 0$ & $0 \times 0$ & $0 \times 0$ \\
\hline OctnLow & DC & 시 & 라 & 솔 & 파 & 미 & 레 & 도 \\
\hline OctnHigh & DC & DC & DC & 라\# & 솔\# & 파\# & 레\# & 도\# \\
\hline 1. OctnLow : Low byte of nth $\propto$ ctave white key \\
information \\
2. OctnHigh : High byte of nth octave black key \\
information \\
3. DC : Don't care bit
\end{tabular}

표 3. Data packet의 byte 구조 Table 3. Byte structure of data packet

\begin{tabular}{|c|c|c|c|c|c|c|}
\hline $\begin{array}{c}\text { MS } \\
\text { B }\end{array}$ & & & & & & LSB \\
\hline & $\begin{array}{c}\text { Oct } \\
2 \\
\text { Hig } \\
\text { h }\end{array}$ & $\begin{array}{c}\text { Oct } \\
2 \\
\text { Low }\end{array}$ & $\begin{array}{c}\text { Oct } \\
1 \\
\text { Hig } \\
\text { h }\end{array}$ & $\begin{array}{c}\text { Oct } \\
1 \\
\text { Low }\end{array}$ & $\begin{array}{c}\text { Oct } \\
0 \\
\text { Hig } \\
\text { h }\end{array}$ & $\begin{array}{c}\text { Oct } \\
0 \\
\text { Low }\end{array}$ \\
\hline
\end{tabular}

1. OctnLow : Low byte of nth octave white key information

2. OctnHigh : High byte of nth octave black key information 
$\mathrm{PC}$ 와의 USB통신을 위해 그림 4와 같이 firmware를 구 현하여 상태 정보를 polling하고 그 결과를 64 바이트 패킷 을 작성하여 버퍼에 저장한다. 그리고 $\mathrm{PC}$ 로부터 송신요청이 있을 경우 USB 통신을 통해 건반 입력정보를 전송하게 된다.

옥타브 당 데이터 패킷 구성은 표 2와 같다. 건반마다 독 립적으로 1 비트 값을 가지며, 옥타브당 흰 건반 1 바이트, 검은 건반 1 바이트 씩 모두 2byte로 구성된다. 4 옥타브로 구성되는 건반에 대한 전체 패킷은 표 3과 같이 총 64 바이트 패킷으로 구성된다. 작성된 패킷은 $\mathrm{PC}$ 로 전달되어 처리된다.

\section{PC 기반 연주 소프트웨어 구성}

Software는 저학년 아이들이 편리하게 이용할 수 있도록 전자악기와 연동이 되도록 개발하였고, 연주 기능을 제공하며 전자건반악기를 통한 입력을 받아들일 수 있도록 하였다. 전 체적인 software의 블록도는 그림 5 와 같다.

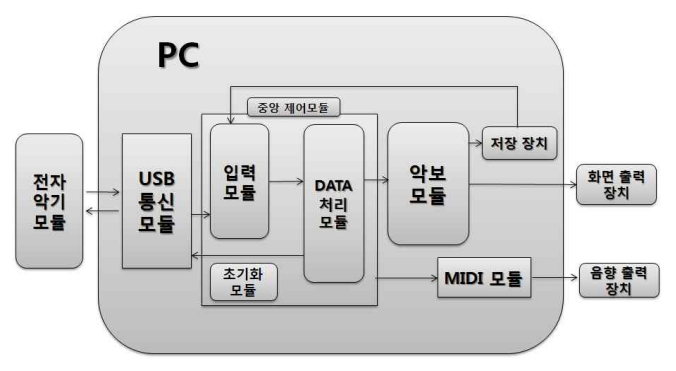

그림 5. 소프트웨어의 블록도

Fig. 5. Software Block Diagram

\section{1 중앙 제어 모듈}

중앙 제어 모듈은 외장전자악기 모듈의 입력을 실시간으로 인지하기 위해 USB 통신모듈을 $20 \mathrm{~ms}$ 주기로 polling 한다. Polling timer event에서는 USB모듈을 통해 전자건반악기 의 상태정보를 읽어 들이고, 박자 timer event에서는 전자건 반악기의 입력 값이 유지되는 형태에 따라 그림 6과 같이 박 자수를 누적시킨다. 전자 건반악기의 건반 누름 지속시간을 측정하기 위해 $\mathrm{BPM}$ (Beat Per Minute) 값을 기준으로 16 분 음표의 가중치를 곱하여 박자 timer 값으로 설정하며, 16 분 음표는 1 tick (0b00001), 8분 음표는 2 tick (0b00010), 4분 음표는 4 tick (0b00100), 2분 음표는 8 tick (0b01000), 온음표는 16 tick (0b10000)이 소요된 다. 점을 가진 음표는 메인음표의 절반만큼의 연주길이를 더 가지게 된다. 그러므로 누적값이 $24(16+8)$ 를 초과할 경우 건반을 새로 누른 것으로 간주하여 처리하였다.

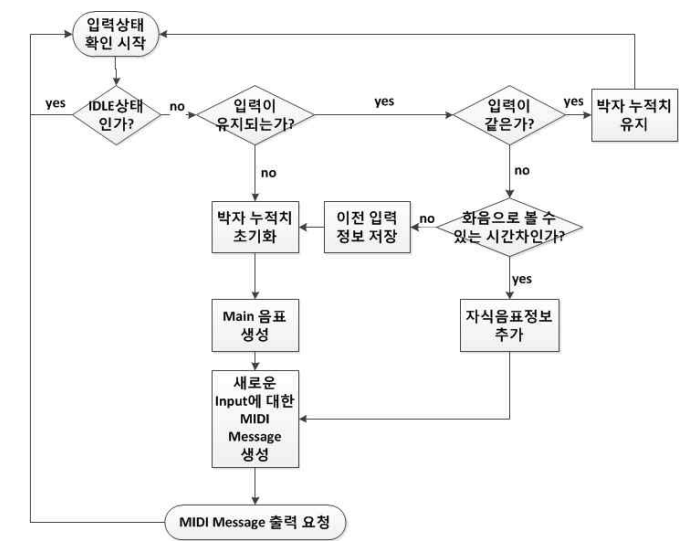

그림 6. 입력상태 확인을 위한 흐름도

Fig. 6. How chart to identify the input status

누적된 박자수를 분석하기 위해서는 10진수를 2진수로 변환하는 방법을 사용하여 변환된 2진수의 5 자리 (온음 표 16분음표)의 2진수로 변환한다. 변환된 5자리의 2진수 에서 0 이 아닌 가장 높은 자리수의 2 진수를 음표구성의 메인 박자수가 되며 차 하위 자리수에 값이 1 이면 점(.)을 구성하 는 정보가 된다.

악보정보 처리를 위한 자료구조는 각각의 음표정보가 편집 및 삭제, 추가가 자유롭도록 list 구조를 선택하였다. List를 구성하는 각각의 노드는 화음을 표현하기 위해 입력된 음표정 보 중 가장 낮은 음을 메인노드로 설정하였다. 하나의 메인노 드는 최대 5 개의 자식음표 정보를 담을 수 있으며 연주시에 메인노드와 자식노드의 정보를 동시에 $\mathrm{MIDI}$ 모듈로 전달하 여 화음이 연주되도록 구현하였다.

그림 7은 메인노드 클래스의 속성 값을 나타낸다. 메인노 드 클래스는 자식노드 클래스의 속성 값뿐만 아니라 자식노드 의 개수와 화면에 표시될 위치정보를 포함한다. 자식노드 클 래스의 화면 내 표시위치는 메인노드 클래스의 위치정보로부 터 음높이 차이를 통해 계산된다. 하나의 메인 음표에는 최 대 5 개의 자식 음표 정보를 포함시킬 수 있어 최대 6 개까지의 음을 하나의 화음으로 구성할 수 있도록 하였다.

마우스를 사용하여 악보를 입력할 경우 화면에서 음표를 입력될 수 있는 구역(Active Block)을 설정한 뒤, 해당 구역 을 마우스로 누르면 메인노드 클래스의 인스턴스를 생성하여 추가한다. 그리고 5 선지 내의 위치 값을 계산하여 음자리를 결정하여 입력정보를 전달하면 악보모듈에서 입력된 정보를 화면에 출력한다. 


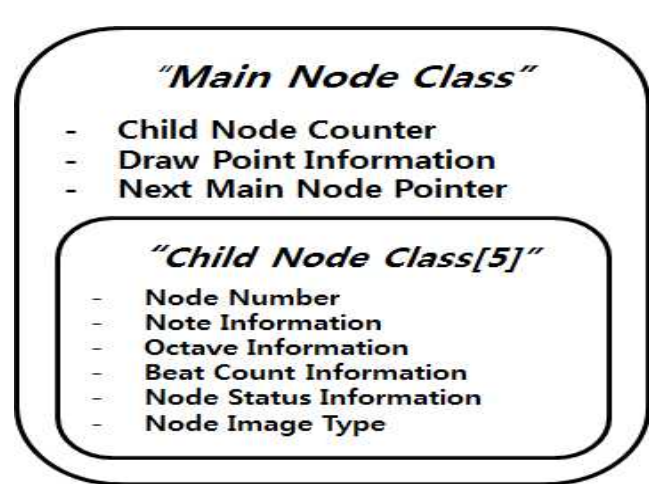

그림 7 음표를 표현하는 Class 구조

Fig. 7. Class structure to represent a note

\section{2 악보 모듈}

악보 모듈은 마우스 또는 전자건반악기로부터의 입력으로 생성된 메인노드 클래스의 List 정보들을 분석하여 화면에 출 력하고, 편집에 필요한 기능들을 제공도록 설계하였다. 악보 를 구성하는 음표, 쉼표, 기호 등의 bitmap Image를 제작하 여 지정된 위치에 해당 이미지가 출력되도록 구현하였다.

화음 음표를 하나의 블록에 그려내기 위해서는 자식 음표 들의 머리방향이 적절하게 왼쪽 방향과 오른쪽 방향으로 나눠 표시되어야 한다. 이 경우 가능한 조합의 모든 음표모양에 대 해 모두 이미지 폰트로 구성할 경우 그 구성이 매우 복잡해진 다. 그러므로 그림 8과 같이 정상적인 음표 머리 방향의 반대 방향을 가지는 음표 머리에 대한 이미지 폰트를 구성하여 이 웃하는 음계의 음표머리에 대해서 좌, 우의 음표머리를 유동 적으로 적용함으로써 표현의 효율성을 높였다. 가장 낮은 음 계인 메인노드는 꼬리를 제외한 형태로 출력하고 이웃하는 윗 음계의 자식음표는 반대쪽으로 머리가 출력되도록 하였다.

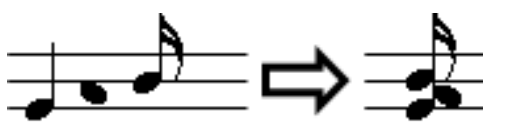

그림 8. 화음 음표 조합의 예 Fig. 8. Example of Note Imge Font Combination

꼬리가 있는 8 분 음표와 16 분 음표가 화음으로 구성된 경 우 같은 방법으로 구성을 하되 머리방향이 정상적인 음표머리 방향을 가지는 가장 높은 음계의 자식 음표를 찾는 과정이 추 가된다. 이는 이미지 폰트의 기둥(대)의 길이가 고정적이기 때문에 가장 마지막의 정상적인 음표머리 방향을 찾아내어 해 당 음표를 출력할 때 꼬리를 가진 이미지 폰트를 출력해 주기 위함이다. 마지막 정상 머리 방향 음표를 제외한 나머지 음 계에서는 4 분 음표의 이미지 폰트를 출력한다.
뒤집힌 화음 음표의 경우는 메인 음표가 꼬리를 가진 이미 지 폰트로 선택되며 그 이외의 모든 음표는 머리 방향만 변경 된 4 분 음표의 이미지 폰트들의 조합으로 출력하게 된다.

\section{$2.3 \mathrm{MIDI}$ 모듈}

Window MIDI API를 이용하기 위해 MIDI Message를 구성하는 역할을 담당한다[13]. $\mathrm{MIDI}$ 모듈은 중앙제어모듈 로부터 악기 및 음표정보를 전달받아 음표 연주 Event에 대 한 정보, 채널정보, 음높이, 건반을 누르는 세기 정보 등을 분 석한 뒤, 그림 9 와 같이 3 byte로 구성되는 $\mathrm{MIII}$ message 를 생성한다. $\mathrm{MIDI}$ short message 하나가 완성이 되면 midiOutShortMsg() API를 통해 $\mathrm{OS}$ 에 해당 $\mathrm{MIDI}$ message의 처리를 요청함으로써 해당 음표의 연주를 시작한 다. 음표 각각의 연주시간은 타이머 이벤트를 설정하여 제어 한다. 각 음표에 할당된 시간 이후에 타이머 이벤트가 발생되 면 해당 음표별로 NoteOnEvent 값이 0 인 MIDI message 를 생성, 처리를 요청하여 출력을 off 시킨다.

\begin{tabular}{|c|c|c|c|}
\hline \multicolumn{2}{|c|}{ Status Bit ( 8 bit) } & \multicolumn{2}{|c|}{ Data Bit (16bit) } \\
\hline $\begin{array}{l}\text { Note On event } \\
\quad(4 \mathrm{bit})\end{array}$ & $\begin{array}{c}\text { Channel } \\
\text { (4 bit) }\end{array}$ & $\begin{array}{c}\text { Note Number } \\
\text { (8bit) }\end{array}$ & $\begin{array}{l}\text { Velocity } \\
\text { (8bit) }\end{array}$ \\
\hline $\begin{array}{l}\text { "Channel: Synthesizin } \\
\text { "Note Number 누를 } \\
\text { "Nelocity : 듬의 강도 }\end{array}$ & 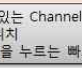 & & \\
\hline
\end{tabular}

그림 9. MIDI Short Message 구성

Fig. 9. MDI Short Message format

\subsection{USB 통신 모듈}

Software상의 USB 통신 모듈은 전자건반악기와의 통신 을 위한 모듈이다. 전자건반악기가 $\mathrm{USB}$ 를 통해 $\mathrm{PC}$ 와 연결 되면 Plug\&Play를 통해 드라이버 설치과정이 수행된다. 이 후 장치 이름인 물리적 Port와 GUID (Global Unique Identifier)를 찾아내고, 하드코딩된 Product $\mathrm{ID}$, Vender $\mathrm{ID}$ 를 비교, 확인하여 Interface handle을 얻어오는 일련의 초기화 과정이 수행된다.

$\mathrm{PC}$ 에서 외장 전자건반악기 모듈로부터 건반누름 정보를 수신하는 과정은 그림 10 과 같다. 먼저 WinUsb_Write Pipe() API를 이용하여 명령어 코드 0x80와 Endpoint 지 정 $0 \mathrm{x} 01$ 을 USB Pipe를 통하여 외장 전자건반악기 모듈로 전달한다. $\mathrm{USB}$ 와 연결된 전자건반악기는 $\mathrm{PC}$ 로부터 명령어 코드를 수신한 후, 건반의 입력상태를 읽어 들여 Endpoint1 을 가지는 $\mathrm{USB}$ 출력 $\mathrm{Pipe}$ 를 통해 $\mathrm{PC}$ 로 $\mathrm{Data}$ 를 출력하게 된다. 이후 PC 단의 USB 통신 프로그램에서는 입력된 Data 를 WinUsb_ReadPipe() API함수를 통해 건반누름 정보를 수신한다. 
USB Communication Flow to Read Key Input Data

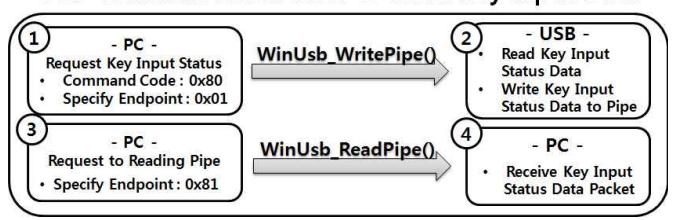

그림 10. Key 입력정보를 얻기 위한 USB 통신 흐름 Fig. 10. USB Communication How to Read Key Input Data

\section{III. 실험 및 결과 분석}

설계된 내용을 바탕으로 직접 software와 외장 전자건반 악기를 구현하고 연동 실험을 통하여 firmware, polling 주 기 변화에 따르는 인식차이, 외장 전자건반악기를 제작하는데 필요한 비용 분석을 수행하였다.

Software는 Windows 7환경에서 NET framework 2.0 과 $\mathrm{MFC}$ Dialog기반으로 제작하였고 Window Driver Kit (ver. 6001.18001)을 사용하였다. 그림 14의 외장 전자건 반악기는 MPLab 7.6을 통해 firmware를 구현하였고 $\mathrm{ROM}$ writing을 위해 EETools를 사용하였다.

먼저 외장 전자건반악기를 USB 연결로 $\mathrm{PC}$ 와 접속하였을 때 firmware를 통해 Window 운영체제가 전자건반악기를 인식하고 드라이버를 작동시키는지 확인 하였다. 그림 11 과 같이 최초 접속에서는 드라이버 설치를 요구받게 되고 정보파 일(.inf file)을 설치한 후 접속 즉시 정상적으로 동작함을 확 인 하였다.

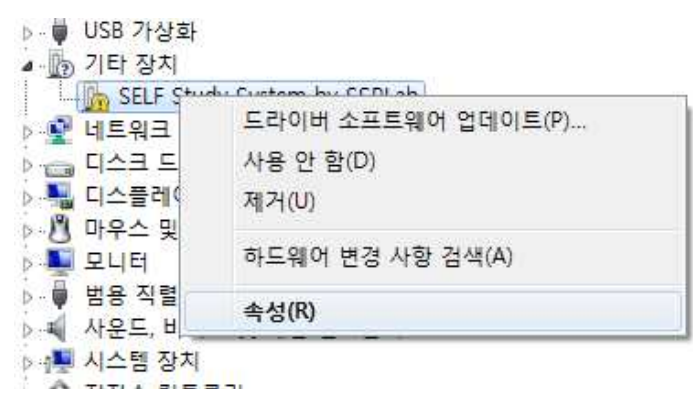

그림 11. USB Interface 전자건반약기 설치 화면 Fig. 11. Install Windows for an electronic keyboard

다음으로 polling 시간에 따른 이용자들의 인식 정도를 실 험해 보았다. Polling 주기는 하드웨어적으로 최소 42us가 될 수 있으나, Window API함수인 SetTimer로 지정 가능 한 시간이 $1 \mathrm{~ms}$ 이므로 최소 $1 \mathrm{~ms}$ 부터 $100 \mathrm{~ms}$ 까지 변경하여
실험하였다. 평가는 건반악기를 다루어 본 적이 있는 대학생 5 명을 대상으로 5점 만점 (차이가 거의 못 느껴질 경우 5점) 으로 실제 악기와의 응답 차이 인지도를 검사해 보았다. 실험 결과 그림 12 와 같이 $20 \mathrm{~ms}$ 이하이면 실시간 연동이 되는 것 으로 인지하였기에 전력소모를 고려하여 polling 주기를 $20 \mathrm{~ms}$ 로 정하였다.

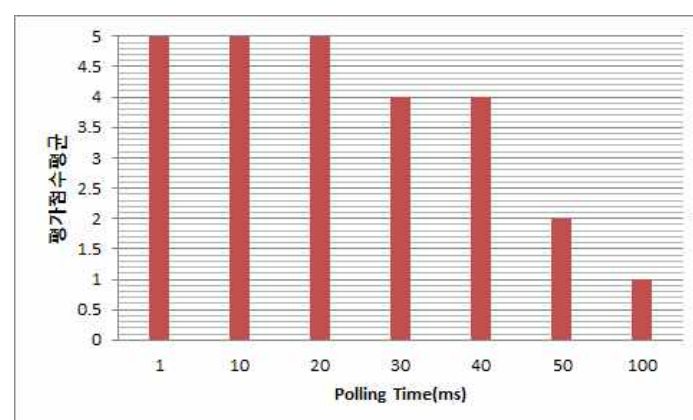

그림 12. 인지 테스트 결과

Fig. 12. The result of perception test

그리고 일정시간 동안 건반의 누른 횟수와 polling 주기로 입력된 데이터 상의 level 변동 횟수를 비교하여 입력 오류발 생 여부를 검증하였다. Polling 주기가 $20 \mathrm{~ms}$ 일 때 그림 13 과 같이 사용자가 빠르게 건반을 누른 경우에도 최소 2 번의 표본화가 이루어졌다. 그리고 건반을 누른 횟수와 $\mathrm{PC}$ 상에서 인식한 level 변동 횟수가 같은 값을 가지며 입력이 없는 동 안 오인식된 경우가 없음을 확인하였다.

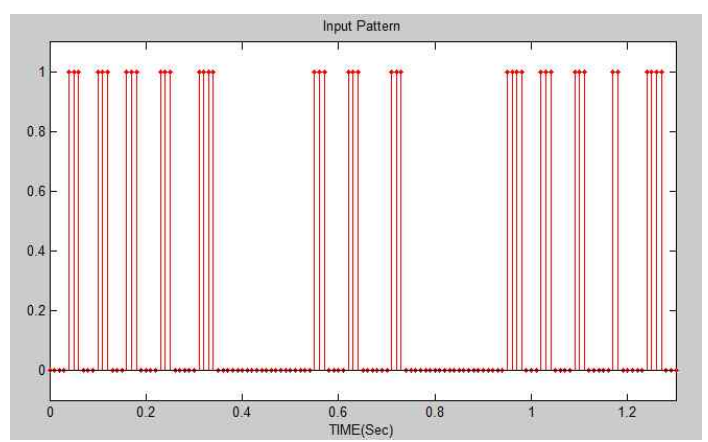

그림 13. 건반 입력 패턴 확인 실험 Fig 13. Keyboard input pattem matching test 
표 4. 전자건반악기에 사용된 주요 부품

Table 4. main part list for Eectronic Keyboard Instrument

\begin{tabular}{|l|l|}
\hline 부품명 & 수량개) \\
\hline PIC18F4550 & 1 \\
\hline MAX7219 & 4 \\
\hline 4Digit Segment & 2 \\
\hline Two-tone LED & 30 \\
\hline Button Switch & 30 \\
\hline
\end{tabular}

마지막으로 전자건반악기에 사용된 주요 부품들은 표 4와 같이 하나의 전자건반악기를 제작함에 있어서 packaging에 들어가는 비용을 제외하고는 실제 악기 가격 대비 매우 저렴 하게 제작할 수 있음을 알 수 있다.

본 논문에서 제안한 건반악기연주 자율학습을 위한 전자악 기의 구현 결과는 그림 14 , 그림 15 와 같다.

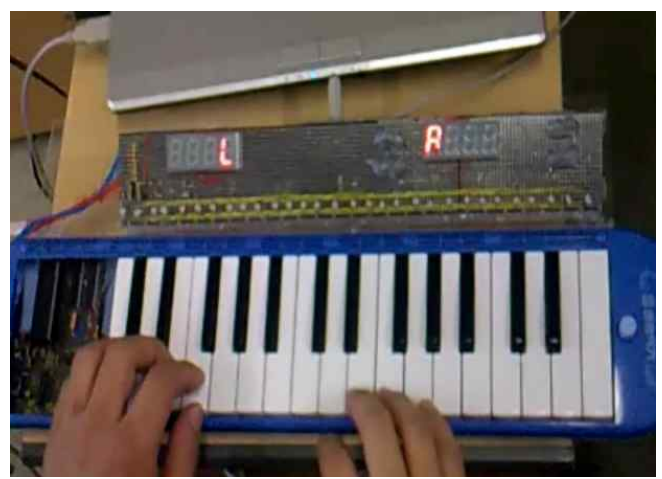

그림 14. USB Interface 전자악기 연주

Fig. 14. The Electronic Keyboard Instrument play using the USB interface

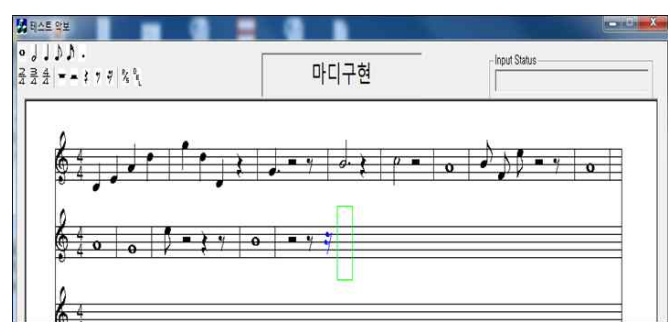

그림 15. 악보 프로그램 (Software) Fig. 15. Notation Program (Software)

\section{IV. 결 론}

본 논문에서는 초등학교 저학년 학생들이 악기연주를 학습 할 때 학습 성취도를 높이고, 자기주도적 학습이 이루어질 수 있도록 하기 위한 한 방법으로서 USB interface를 이용한 전자건반악기 구현, 그리고 전자건반악기와 연동되는 $\mathrm{PC}$ 기반 지원 software개발에 대하여 연구하였다.

본 연구를 통해 software, 전자건반악기를 직접 설계, 제 작함으로써 저렴한 가격으로 학습 System을 제공할 수 있음 을 확인하였다. 또한 USB Interface를 적용한 전자건반악기 와 $\mathrm{PC}$ 기반 software가 연동하여 자유롭게 연주하고, 연주를 통해 얻은 악보를 지원 software를 통해 다시 들어볼 수 있 음을 보였다. 외장 전자건반모듈은 USB를 지원하는 $\mathrm{PIC18F} 4550 \mathrm{MCU}$ 를 활용함으로써 간결한 구조와 저비용 으로 구현하였다. 그리고 $\mathrm{PC}$ 상에서 수행되는 software는 악보편집, $\mathrm{MIDI}$ 정보 처리, 외장 전자건반모듈과의 상호연동 을 통하여 건반악기와 유사한 환경을 지원함으로써 향후 자율 학습용 컨텐츠가 추가될 경우 전자건반악기 연주 자율학습에 활용이 가능하다고 판단된다.

이를 통해 값비싼 악기에 접근하기 힘든 저학년의 초등학 생들이 음악과 악기에 대한 이해 및 접근성을 높이고, 창의성 과 음악적 능력을 향상시킬 수 있는 가능성 뿐만 아니라 악기 연주의 대중화에 기여하고자 한다.

본 논문에서 제시한 방법은 그 가능성을 제시하기 위한 것 으로 아직 보완이 필요하다. 향후 효율성 높은 자기주도적이 면서 학습자 중심의 음악학습을 위한 연구를 통한 보완작업 을 진행할 예정이다.

\section{감사의 글}

본 연구는 울산대학교 교내 연구지원으로 수행되었습니다.

\section{참고문헌}

[1] Peter Miksza, "Music Participation and Socioeconomic Status as Correlates of Change: A Longitudinal Analysis of Academic Achievement", Bulletin of the Council for Research in Music Education, No. 172, 
pp. 41-58, 2007

[2] C.J. Bonk, and KS. King, "Electronic Collaborators: Learner Centered technologies for Literacy, Apprenticeship, and Discourse," Lawrence Erlbaum Associates Publishers, pp. 25-50, 1998.

[3] MS. Kang, "Sound Engine for Korean Traditional Instruments Using General Purpose Digital Signal Processor," The Journal of the acoustic society of Korea, Vol. 28, No. 3, pp. 229²38, Mar. 2009.

[4] D.H. Seong, "Synthesizing the 'Dan-So' sound using the Physical Model," Proceeding of KIISE Spring Conference 2001, Vol. 28. No. 1, pp. 658-660, Apr. 2001.

[5] S.J. Cho, "Development of Improved String Model for Instruments with Anjok," The Journal of the acoustic society of Korea, Vol. 26, No. 7, pp. 328 333, Oct. 2007.

[6] B.H. Oh, "Modeling of Instrumental Tone Using Low Computation Sinusoidal Synthesis," Proceeding of ASK Fall Conference, Vol. 18, No. 2, pp.185-188, Nov. 1999.

[7] MS. Kang, "Implementation of Non-Stringed Guitar Based on Physical Modeling Synthesis," The Joumal of the acoustic society of Korea, Vol. 28, No. 2, pp. 119־126, Jan. 2009.

[8] C.H. Lee, "Electronic Music Glove Using Sound Card ," The Journal of the acoustic society of Korea, Vol. 21, No. 2, pp. 128 133, Feb. 2002.

[9] MR. Kim, "The Research of the Human Computer Interface using by Music XML," Proceeding of KIEE Summer Conference 2001, pp. 2804-2806, Jul. 2001.

[10] Akai EWI4000S, http://www.akaipro.com/

[11] WX5 YAMAHA Midi Controller, http://www.yamaha.com/

[12] Finale\&SmartMusic, http://www.makemusic.com/

[13] P. Messic, "Maximum MIDI Manning," Greenwich, pp. 31-103, 1998.

\section{저 자 소 개}

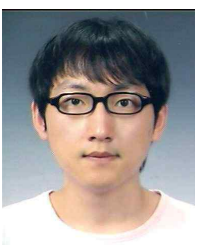

임 기 정

2010 : 울산대학교 컴퓨터정보통신 공학부 공학사.

현 재 : 울산대학교 컴퓨터정보통신 공학부 석사과정

관심분야 : 디지털신호처리, 음성합성

Email : gadama2@gmail.com

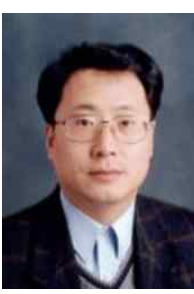

이 정 철

1984 : 서울대학교 전자공학과 공학사

1988 : 서울대학교 전자공학과 공학석사

1998 : 서울대학교 전자공학과 공학박사

19852000 : ETRI 책임연구원

2000년 : L\&H Korea 전문위원

2001년 : (주)보이스텍 전문위원

2002년 : (주)코난테크놀로지 책임 연구원

2002 현재: 울산대학교 컴퓨터정보 통신공학부 부교수

관심분야 : 디지털신호처리, 음성신 호처리, 음성합성

Email : jungclee@ulsan.ac.kr 